\title{
The Impact of Philosophical Inquiry Method on Classroom Engagement and Reasoning Skills of Low Achievers
}

\author{
Wan Mazwati Wan Yusoff ${ }^{1, *}$ \\ ${ }^{1}$ Department of Fundamental and Inter-Disciplinary Studies, International Islamic University Malaysia, Malaysia \\ *Correspondence: Department of Fundamental and Inter-Disciplinary Studies, Kulliyyah of Islamic Revealed \\ Knowledge and Human Sciences, International Islamic University Malaysia, 53100 Kuala Lumpur, Malaysia. Tel: \\ 60-3-6196-6156. E-mail: wanmazwati@iium.edu.my
}

Received: February 27, 2018

Accepted: March 21, 2018 Online Published: April 2, 2018

doi:10.5430/jct.v7n1p135

URL: https://doi.org/10.5430/jct.v7n1p135

\begin{abstract}
This research project attempted to investigate the impact of applying philosophical inquiry method of teaching on classroom engagement and reasoning skills of low achievers. Low achievers are those who have the potential to succeed but lagged behind because of several factors that demotivate them to perform at their highest ability. In this study, low achievers were students who failed or obtained the lowest grades in previous standardized school examination. They were 22 students aged 12-13 years old from a school in Gombak district, Malaysia. The students were observed and video recorded while participating in discussing the questions they had formulated in response to the given stimulus materials. Many assumed and projected that these students would not succeed in school and life; and would not have the intelligence to engage in discussion that employed higher order thinking. However, the findings revealed that when low achievers were given opportunities to voice out their opinions in dialogic pedagogy, they demonstrated the ability to be focused and engaged in classroom discussion. Furthermore, this pedagogy has proven effective in stimulating higher order thinking or reasoning skills among low achievers. Specifically, this study found indicators of behavioral, emotional and agentic engagement among low achievers; and demonstrated that low achievers were capable of asking higher order thinking questions, clarifying meanings, giving examples, making conclusion and inductive reasoning, distinguishing and classifying ideas.
\end{abstract}

Keywords: philosophical inquiry, low achievers, dialogic pedagogy, classroom engagement, reasoning skills

\section{Introduction}

Low achievement is measured by the variance between the actual achievement and the potential achievement. This means that low achievers are capable of achieving specific grades through traditional means of evaluation, however they failed to achieve for several reasons (Chakrabarty \& Saha, 2014; McCoach, 2001; Marks, 2000). Low achievement is correlated to a myriad of negative consequences. Therefore, the issue of low achievement must be one of the main agenda of any education system. Studies have revealed that low achievement is one of the strongest predictors of future failure in school (Williamson, Applebaum, \& Epanchin, 1991; Capella \& Weinstein, 2001; Shaywitz et al., 1995); school dropout (Battin-Pearson et al., 2008); and school suspension and retention (Ergle, 2003; Sheryl, Stephanie, Herrenkohl, Toumbourou, \& Catalano, 2014; Jones, 2013). Other negative impacts of low achievement are anti-social behaviors (Rogers \& Feller, 2016; Rubin, 2006) and delinquency (Felson \& Staff, 2006; Bryant, Schulenberg, O’Malley, Bachman, \& Johnston, 2003).

A vast majority of studies found that low achievers exhibit predictable behaviors. They are disruptive in the classrooms (Tremblay et al., 1992; Ellis, Hart, \& Small-McGinley, 2001; Kamal \& Bener, 2009); play truant (Mijinyawa, Bakar \& Muhammad, 2015; Ishak \& Fin, 2015; Bobakova, Geckova, Klein, Dijk \& Reijneveld, 2015); they have poor motivation and poor self-esteem (Guay, Boivin, \& Marsh, 2003; Reiss, 2009); poor academic self-concept and poor self-confidence (Zhang, Zhao, \& Yu, 2010; Sagor \& Cox, 2004; McCoach, 2001; Chakrabarty \& Saha, 2014); and they have poor engagement in classroom activities (Finn \& Rock, 1997; Furlong \& Christension, 2008; Legault, Demers, \& Pelletier, 2006; Crumpton \& Gregory, 2011; Maynard, Salas-Wright, Vaughn, \& Peters, 2012). Studies have reported positive correlation between student classroom engagement and academic achievement (Kennedy, 2010; Wang \& Holcombe, 2010; Dotterer \& Lowe, 2011; Reyes, Brackett, Rivers, White, \& Salovey, 
2012; Wang \& Eccles, 2012; 2013). Student engagement with school also has been shown to prevent school dropout, nurture motivation to succeed in academic and produces longitudinal changes in classroom motivation (Connell, Spencer, \& Aber, 1994; Finn \& Rock, 1997; Jimerson, Campos, \& Greif, 2003; Christenson, Sinclair, Lehr, \& Godber, 2001; Sinclair, Christenson, Lehr, \& Anderson, 2003; Reeve \& Lee, 2014). Therefore, one way to rectify the problems associated with low achievement is by increasing classroom engagement (Marks, 2000).

Engagement is a student's persistent effort with positive emotion to stay focused in participating in learning activities designed to achieve the set learning goals (Skinner and Belmont, 1993; Marks, 2000; Audas \& Willms, 2001; Christenson, Reschly, \& Wylie, 2012). Engagement is a latent construct which has been explained as consisting of two (Marks, 2000; Willms, 2003), three (Jimerson, Campos, \& Greif, 2003) and four dimensions which are behavior and emotion; behavior, emotion and cognition; and behavior, emotion, cognition and agency respectively (Christenson et al., 2012; Fredricks, Blumenfeld, \& Paris, 2004; Reeve, 2013; Reeve \& Tseng, 2011; Skinner, Kindermann, Connell, \& Wellborn, 2009). These dimensions are interrelated and reciprocally supportive. Behavioural engagement is indicated by students' effort, persistence, attention, absorption and participation in learning activities. Emotional engagement is manifested by students' positive emotion while doing their tasks including interest, enthusiasm, enjoyment, satisfaction and pride (Skinner, Furrer, Marchand, \& Kindermann, 2008). Cognitive engagement is indicated by students' investment in learning to achieve learning goals including employing good learning strategies and study skills (Fredericks, Blumenfeld, \& Paris, 2004). The latest dimension of student engagement is agentic engagement. It is referred to as the degree of students' positive involvement during teaching and learning processes including asking questions, disclosing their choices, thoughts, needs and wants (Reeve, 2013). In agentic engagement, students are not merely reacting to the learning activities designed by teachers but they also get involved in stating their preferences of learning activities and environments conducive to their own unique learning styles.

In Malaysia, it is a customary practice to group low achievers together in one class and the low achievers are labelled as those who would not succeed in academic and in future life. They are assumed as students who possess low cognitive ability and therefore would not be able to participate in classroom discussion and learning activities; what is more to be engaged in intellectual discussion. But how to motivate low achievers to be engaged in classroom activities so that the problems associated with low achievers can be reduced or rectified? Fortunately, we have not exhausted in applying teaching methods that can be proven effective in promoting classroom engagement and participation in discussion using higher order thinking. From an extensive review of literature, we found that intervention program called Philosophy for Children (P4C) has shown promising results in promoting classroom engagement (Schjelderup, 2009; Gasparatou \& Kampeza, 2012; Cassidy, 2013; Topping \& Trickey, 2014; Colom, Mariyon, Magro, \& Morilla, 2014; Faira et al., 2015).

Philosophy for Children program was the brainchild of Matthew Lipman who invested his time to create a program to promote excellent thinking among adolescent and children in America for he was dismayed with their quality of thinking (Lipman, 2003). Since 1974, this program has developed into a world renown program and has been adopted and adapted by many researchers and practitioners throughout the world. Thousands of research have been conducted to discover how this program could help children and adolescent to think well. In Malaysia, Professor Rosnani Hashim and her team from the International Islamic University have been conducting research to provide evidences of the effectiveness of this program in promoting good thinking (multidimensional which consist of critical, creative, ethical spiritual and collaborative thinking), communication skills and self-concept (Rosnani Hashim, 2012; Juhasni Adila, 2010; Preece, 2012; Wan Mazwati \& Lina Mursyidah, 2016). She adapted this program and renamed it as Hikmah Pedagogy to suit the environment in Malaysia where the word philosophy is looked at with suspect.

Hikmah Pedagogy uses philosophical inquiry method to incite students to ask philosophical questions and to engage in philosophical discussion. The main tools in asking and discussing philosophical questions and answers are philosophical thinking skills which include critical, creative, caring and collaborative thinking skills. Professor Rosnani has established the Centre for Teaching Thinking at the Kulliyyah of Education, International Islamic University Malaysia. Many of the research done by Professor Rosnani and her team involved participants who were mediocre and good students. Nevertheless, no study has been done in Malaysia to discover whether this method can promote classroom engagement and stimulate reasoning skills among low achievers. Several studies reported that low achievers were able to ask higher order thinking questions and were able to engage in philosophical discussion (Jenkins \& Lyle, 2010; Spiteri, 2013; Youssef, Campbell, \& Tangen, 2016; Gorard, Siddiqui, \& See, 2016). Therefore, this study was conducted to look for evidences of low achievers' ability to be engaged in all four dimensions of engagement in philosophical inquiry sessions; and to discover whether philosophical inquiry method could stimulate reasoning and discussion among low achievers. 


\subsection{Philosophical Inquiry}

Inquiry is an activity of searching for answers to specific problems. Philosophical inquiry is a quest for answers in philosophical problems. The inquiry is philosophical when it investigates issue that is common, contestable and central (Lipman, 2003). Examples of such issues are the concept of happiness, moral values, existence, knowledge and so on. The pedagogy of philosophical inquiry follows specific procedures. Students are seated in U-shaped seating arrangement to promote two-way communication between students and students and students and teacher. Firstly, on the first session, teacher and students discuss to establish and agree on rules and procedures to be followed during the sessions. Next, students are given stimulus materials in forms of stories, pictures, poems, newspaper clippings, and videos. Students are asked to read, observe, watch and analyse the stimulus materials and they are encouraged to ask questions based on the stimulus materials. The questions asked by students will be written on the whiteboard. Students are expected to ask philosophical questions which emerge out of curiosity, cognitive dissention, and absurdity of experience (Golding, 2006). Philosophical questions “....are essentially contentious. They do not call for correct answer. They demand further investigation and admit of different answers that may have one merit or another...They require students to think for themselves" (Cam, 1995: 15). Subsequently, students discuss to answer the questions that they have raised. The role of teachers is to facilitate the discussion and ask more probing questions so that students are able to clarify, justify and defend their answers or beliefs and to make sound conclusion. Dialogue is the most significant procedure of philosophical inquiry method. Studies demonstrate that dialogue is an effective tool to stimulate classroom engagement (Rubin, 2006; Murphy, Wilkinson, Soter, Hennessey, \& Alexander, 2009; Walker, Wartenberg, \& Winner, 2012; Slakmon \& Schwartz, 2014; Gillies, 2015).

Dialogue is concluded as the primary philosophical skill (Ross, 1993). It involves the process of questioning-and-answering for the purpose of arriving at some truth. Socrates developed a method of dialogue that is interrogative similar to a lawyer's grilling a witness at the stand. German philosopher, Leonard Nelson (1882-1927) founded the modern Socratic dialogue as a method of teaching. In a Socratic dialogue, members are expected to postulate their claims and ideas; and clarify and argue so that they could reach at some consensus on the issues discussed (Nelson, 1993). The aim of Socratic dialogue, according to Nelson, is to assist students to use their own thinking to answer their own questions.

Dialogue is an important part of doing philosophical inquiry and dissimilar to a conversation, dialogue aims for truth or some kind of conclusions however partial they may be (Lipman, 2003). Staying true to the adage of Socrates, Lipman maintains that "in a dialogue, each argument evokes a counterargument that pushes itself beyond the other argument and pushes the other beyond itself" (p: 87). Dialogue implicates communal investigation of thoughts and prospects, examination of norms and held beliefs, and exploration into the unfamiliar or mysterious to discover new interpretation or knowledge. Dialogue is done cooperatively and collaboratively.

Inquiry method used in Philosophy for Children has been proven effective in promoting students to ask higher order thinking questions (Haynes \& Murris, 2011; Topping and Trickey, 2014); to share their experiences and listen to others (Spiteri, 2009; Dasi, Quintanilla, \& Daniel, 2013; Barrow, 2011); to answer their own questions, ask for clarifications, reason, and justify their own views (Millet \& Tapper, 2011; Ghaedi, Mahdian, \& Fomani, 2015; Cassidy, 2013); and to discuss things that are relevant to students (Letseka, 2014; Jones, 2012; Youssef, 2014). These studies also reported that students' self-confidence, satisfaction in learning and schooling had increased substantially. Students are engaged in learning when they try to formulate questions based on stimulus materials, clarifying their questions and opinions, justifying their claims which are relevant to their life. These activities not only promote behavioural engagement but also cognitive engagement. When students are satisfied with learning and schooling and their self-confidence increases, they are engaged emotionally. In philosophical inquiry method, students are given freedom to choose the topics of their interest, the stimulus materials to be used and how the sessions should be handled. Students are also given the opportunity to facilitate the sessions. This means that this method could also enhance agentic engagement.

\section{Method}

This study employed qualitative research method, specifically case study method. Case study is defined as "an empirical inquiry that investigates a contemporary phenomenon within its real-life context; when the boundaries between phenomenon and context are not clearly evident; and in which multiple sources of evidence are used" (Yin, 1984: 23). Specifically, this study used evaluative case study method to describe, explain, and make judgment on an intervention program (Merriam, 1988). This method is employed to evaluate an intervention program when the program is speculated to produce an assortment of results (Yin, 1992). Particularly, this method is used to describe the background in which philosophical inquiry method was applied and to explain the impact of the philosophical 
inquiry method on students' engagement in classroom and their questioning and reasoning skills. The researcher's role in this research was as a participant observer and she conducted the teaching and learning sessions for she was a certified trainer and professional in philosophical inquiry method. The certification in Philosophy for Children was awarded by the Institute for Advancement of Philosophy for Children, Montclair State University, Newark, New Jersey.

\subsection{Participant Characteristics}

The participants were a class of 22 low achievers aged 12 and 13 years old from Sekolah Menengah Gombak Setia, Selangor, Malaysia in 2017. Students from this class were selected because the school classified them as low achievers based on previous exam results and they exhibited the characteristics of low achievers discussed in the introduction of this report. The school reported that students from this class were noisy, distracted, engaged in verbal arguments and rude; and they would not sit at their places, would come in and get out of class anytime they felt to do so, and would disturb their friends during teaching and learning sessions. Absenteeism was very high. The school administrator approved the request by the researcher to conduct eight philosophical inquiry sessions. However, since the school had programs that required all students to participate, we had only managed to conduct five sessions, which were enough to gauge the students' engagement and their ability to ask higher order thinking questions and employ reasoning skills. Philosophical inquiry method was used to teach a social science subject called "civic".

Each philosophical inquiry session followed a specific pattern. Students were given stimulus materials in the form of fictional stories, pictures, and non-fictional text; and they also played philosophical games. Students were instructed to sit in U-shaped seating arrangement and were asked to read the texts given to them aloud, one after another, a paragraph at a time. After that they were given quiet time to think and write down questions in their note books. Then, they were asked to share their questions and the teacher wrote their questions on the whiteboard. Their names were written at the end of their questions. When the stimulus material was a picture, they were asked to observe the picture and formulate questions that interest them. Each student was given a chance to ask at least one question. Afterward, students categorized the questions on the whiteboard and they chose the questions they wanted to answer first. The role of the teacher was to facilitate the sessions; and to ask more probing question for clarification and deeper understanding. Data collections were focused on the questions asked by students, the discussion, and the effort given to complete tasks given by the teacher. These were done to look for evidences of behavioural, emotional, cognitive and agentic engagements.

Further, other data collected in this study were questions asked by students based on the given stimulus materials; oral and written responses given by students in the discussions during teaching and learning sessions which were recorded in video recording and answer sheets; and observation notes taken during the implementation of the sessions. The collected data were analyzed using qualitative data analysis procedure. Students' questions and responses during discussions; and students' answer sheets were analyzed to determine whether students were engaged in higher order thinking or philosophical discussion; and applied higher order thinking to clarify meanings and justify their responses. Observation notes were analyzed and coded according to predetermined themes.

\section{Results}

The researcher and her assistant were greeted with "welcome to the hell" written on the door of the classroom. The behaviour of the students fit the descriptions given by teachers who taught this class and the descriptions reported in the literature on low achievers. The first and the second session were difficult to handle because much time was spent on managing students' disruptive behaviours. However, students were surprised when they were told to ask questions and collaborate to answer questions because they were used to be told to stay quiet and listen to the teachers. They found this activity was so odd that they started to calm down and concentrate on formulating questions. The results of this study revealed students' questioning skills, reasoning skills and classroom engagement.

\subsection{Students' Questioning Skills}

Students are used to answering questions that they face difficulties to formulate their own questions. The main feature of philosophical inquiry method is students are given some stimulus materials and they have to ask questions based on the stimulus materials. Question is a powerful tool to stimulate thinking (Elder \& Paul, 2003). Asking question paves the way to new findings and new knowledge, that is why every research project requires asking relevant questions. Thinking, which is the requirement for learning, occurs when questions are asked (Elder \& Paul, 2003). In this study, there were four types of questions asked by the participants. All of the students were able to ask factual question, that is, question that assesses comprehension of the read text. Answers to factual questions can be 
found in the stimulus materials. Some of factual questions asked by the participants were: Who borrowed the cauldron? Who is his neighbour? What was the neighbour's reaction when he was told that the cauldron had given birth to a smaller pot? Where does he live? Where have you been? Who painted the picture?

The second type of question asked by the students were prediction or speculative questions. The answers to this question were not in the stimulus materials but the evidences that point toward some future events can be found in the stimulus materials. The particular stimulus materials given to these students did not contain evidences of future events but students made predictions based on their experiences. Only ten students were able to ask speculative questions. The following are some of the speculative questions asked by the students: Why did he not return the cauldron? Why did his neighbour's wife ask for the cauldron? What would happen if he did not return the cauldron? Is it going to rain? What would happen if there is no name?

Majority of students possessed the ability to ask questions that require some research. The answers to these questions could not be found in the stimulus materials (stories and texts) but the students can find the answers by searching the internet or reading books. Most of them asked the same questions. They were curious to know the answers to the following questions: Who is Hoca? Where is he from? How far is from here to Africa? What is the difference between cauldron and pot? Why did the girl wear that kind of clothing? Who was the sultan?

The forth type of question asked by the students were questions that asked for reasoning, clarification of meaning, and deliberation on moral issues. According to Cam (2006), these types of questions are called philosophical questions. Philosophical questions are thinking questions since one has to use higher level thinking to answer these questions. The following questions were asked by the students: Is it right to take someone else's things? Is it right not to return things we borrowed? Is it right to lie? Why do we go to school? Why names of things differ? Why do parents give us names? Why do we have names? What is name? How can we have good moral behaviour? Is it rational to believe in something that is impossible?

\subsection{Clarifying Meanings, Giving Examples, Making Conclusions and Classification}

It was generalized that low achieving students would have difficulty in giving opinion, asking open questions, clarifying and defining, giving examples, making conclusion, and they would not exhibit thinking ability. However, from the first session, it was evident that low achievers could ask higher order thinking questions and engage in higher order thinking discussion. In response to the topic 'name', students were able to ask four thinking questions and deliberate to answer those questions. The noisiest boy responded to the question "does anybody have to have name?" by answering, "Yes, we have to have names. If not, we could not differentiate people and it will be difficult to call people... when we call hey! All who are present will answer...”; "And this is confusing”, another boy added and the whole class agreed; and "Knowledge would not be possible because knowledge is recorded using words or names of things". Two girls added that "we cannot communicate if there is no name...if things are within our sight, we can just point to the things...but we cannot communicate through telephone". This suggests that the students can reason well and can foresee what would happen if there is no name, namely 'confusion', 'no knowledge', and 'cannot communicate'. They also entertained the possibility of determining a person's personality by his or her name. After giving examples of few of their friends who had the same name, they concluded that names could not tell one's personality because their friends had different personalities even though they shared the same names. This is another evidence that low achievers can think and strategize to find answers. They also concluded that they could tell one's gender, race, and religion from one's name.

To assess their ability to define a concept, the students were given a scenario in a furniture shop where they wanted to buy a table but they did not know the word 'table' and there was no table in the shop. The students explained that they had to describe the features of the table. Other students added that they should also describe the functions of the table. At the end of this discussion they concluded that the word 'table' represent a thing with certain physical characteristics and functions. They further concluded that name of an object "conveys features and functions of the object (melambangkan ciri-ciri dan fungsi benda itu)". This means that low achievers can articulate their ideas well; make logical conclusion; and clarify meaning of a particular word.

During the third session, students were asked to say a word out loud one by one. Then, the words were written on the whiteboard. There were a total of 22 words and students were instructed to classify those words and name each class. The words were bridge, house, diamond, chair, desk, watch, fan, pencil, pot, motorcycle, lamp, eraser, spoon, bicycle, window, pen, wok, door, book, shoe, bag and water bottle. Students were asked to discuss in groups and come up with their classifications. The students selected their own group members and they grouped into six groups. Three groups classified the words into six categories and the other three groups grouped the words into seven categories. 
The categories were 'things for school'; 'kitchen tool'; 'vehicle'; 'things in classroom'; 'jewellery'; 'constructed things'; 'stationeries'; 'parts of building' and 'hanging things'. This is clear that these low achievers could identify similarities and differences of those words and classify them accordingly. They moved from specific instances to generalized conclusion. In other words, the students were able to do simple inductive reasoning.

Students were given a story in the fourth session. In this session, there was not enough time for thorough discussion. Students read, asked questions and wrote their questions on the whiteboard and classified the questions according to similar themes. The discussion was done during fifth session. It was surprising that the students were able to formulate some lower order and higher order thinking questions. Lower order thinking questions assess comprehension of the story; and answers can be found in the story. Higher order thinking questions assess reasoning skills and answers could not be found in the story. They also noticed some cognitive dissonance present in the stimulus material, that is, the story was about Hoca who told his neighbour that his big cauldron had given birth to a small pot. They wondered how someone could believe that an inanimate object could give birth and die. They came to a conclusion that the neighbour actually did not believe the story but since he gained extra pot because of the story, so he did not refute the story. The students discussed the moral issue of borrowing something from friends and neighbours and would not return them; and the issue of taking someone else's things through deceit. Even though these students were noisy and disruptive but they understood that it is wrong for people to lie, take others' belongings, and hurt others' feelings.

In conclusion, the findings revealed that these low achievers could articulate their views well, clarify meaning, give examples, make conclusion from earlier premises, compare, contrast and classify things, make inductive reasoning, and justify actions based on what is right and wrong. The data also indicated that the students were able to collaborate in small group discussion. This finding is similar to the finding of a study conducted by Jenkins and Lyle (2010). They found that low achievers could formulate higher order thinking questions; use evidence and examples to elaborate and support opinions; evaluate; and they also could think about their own thinking. Other studies conducted by Spiteri (2013), Youssef, Campbell and Tangen (2016) and Gorard, Siddiqui and See (2016) also reported the same findings.

\subsection{Behavioural, Emotional, Cognitive and Agentic Engagement}

Low achievers are viewed as problematic students who are not interested in listening to teachers and doing and completing classroom tasks. However, when the 22 low achievers from this particular school were given stories to read, topics that were relevant to them to discuss, the data showed that they were engaged in discussion and they had completed classroom tasks. Evidences of behavioural engagement were they responded to questions asked by the teacher; and they completed the tasks given to them, that is, they were focused in group discussion to write questions and to classify words. Moreover, the students were known to be the most disruptive students who always walked in and out of classes as they pleased, but during philosophical inquiry sessions, the stayed put in their seats for 50 minutes to complete the tasks given to them. This was the greatest achievement.

Other evidences of behavioural engagement included the students' participation in discussions and they were not distracted by other things such as looking outside of the classrooms, chatting with friends, and playing games. They listened to and followed teacher's instruction and would ask questions to confirm their understanding. Surprisingly, they also listened attentively while their friends were reading and they listened to their friends' comments and reasoning; reacted by agreeing or disagreeing; and sometimes they laughed at their friends' funny responses. Their body language also indicated that they were focused and they displayed good mannerism.

Low achievers are still stereotyped as those who hate school and doing school work. However, this study proved that low achievers manifested positive emotion during philosophical inquiry sessions. The evidences indicated that they were emotionally engaged. They enjoyed reading stimulus materials given to them and the game they played in class. They responded with chuckles when they came across funny stories and when their friends made funny remarks. Further, they anticipated future sessions by saying "please come again next week, we will be waiting for you". They also rewarded themselves with a big applause when they were praised for good behaviour, that is, when they focused and showed interest in completing classroom tasks. They reminded each other to speak politely because they used to be rude when speaking with each other. In addition, they reminded each other to listen to teachers and keep their voices low.

As for cognitive engagement, there was no definite evidence that the students had employed different and effective learning strategy or study skills. Five sessions (a total of 4.5 contact hours) were too short to assess cognitive engagement. However, this study had shown many evidences on their cognitive involvement in responding to the 
stimulus materials and discussions. More time is required to assess low achievers' cognitive engagement. This study also discovered that students asked questions regarding why and how the class was handled. On the second session, they asked reasons for selecting their class and asked permission to suggest some ideas. They asked if they can propose games that they would like to play and activities they would like to do in class. Besides asking questions regarding stimulus materials, these low achievers had demonstrated agentic engagement when they showed interest to give their inputs in teaching and learning sessions.

\section{Discussion}

This study has revealed a deeper insight of the value of philosophical inquiry method in promoting classroom engagement and supporting low achievers' cognitive development. It has shown that dialogues between students and teachers and students and students allow low achievers to demonstrate their ability to ask higher order thinking questions, to use reasoning skills, to engage in question-and-answer sessions and to complete classroom tasks normally associated with good students.

When low achievers were given the opportunities to formulate questions and voice out their opinions, they were engaged in classroom activities and used reasoning skills to deliberate on issues related to their life and experiences. The students in this study reflected on their own experiences to answer questions and make conclusions especially on issues that they can associate with. The quality of their questions and reasoning and the intensity of their focus in completing classroom tasks indicated that teachers have to reassess the capability of these low achievers specifically and other low achievers generally. There is a value in looking at different ways of evaluating students' performance so as not to label students as low achievers for not doing good in standardized exams.

Through participation in doing philosophical inquiry, the students demonstrated behavioural, emotional and agentic engagement and reasoning skills. The findings support Slakmon and Shwartz's (2014) and Gillies' (2015) conclusion that low achievers' participation in dialogic pedagogy promotes classroom engagement. Furthermore, the findings corroborate Haynes and Murris' (2011) and Topping and Trickey's (2014) assertion that philosophical inquiry method promotes students to ask higher order thinking questions. This study also revealed consistent outcomes with a study conducted by Jenkins and Lyle (2010) that low achievers' involvement in dialogues stimulate reasoning skills. A move from one-way communication in classrooms and unvalued opinions of low achievers, dialogue has given them the opportunity to speak their minds; and empowered the students to realize that their questions and opinions have value. This in itself is motivating for children as well as adults like to be appreciated.

This study advances some pertinent issues in the effectiveness of school and national examinations which categorize students as 'good', 'average' and 'poor'. These labels affect teachers' expectation of students which may lead to actions that are detrimental to students' progress. Results of examinations are considered as accurate measurement of a student's ability. As a result, the student is given a curriculum that may not be consistent with their intellectual ability; and may be neglected by teachers and school administrators. In relation to assessing students' achievement, this study recommends looking into the possibility of incorporating qualitative description of students' voices to complement the prevailing quantitative method of assessment.

This study suggests that when students, who are categorized as low achievers based on examination results, are given opportunity to voice out their opinions and their opinions are valued in dialogic pedagogy, they can engage in classroom activities and demonstrate the ability to use reasoning skills. This study attempted to look for indicators of classroom engagement and reasoning skills used among low achievers in philosophical inquiry sessions. Therefore, this study postulates that a prolong application of philosophical inquiry method of teaching could enhance low achievers' higher order thinking skills and engagement with school. The findings of this study only describe the students who were involved in this study. More studies should be conducted to generalize that philosophical inquiry method is indeed effective in enhancing higher order thinking skills and promoting classroom engagement among low achievers. Further research, preferably longitudinal study, should also be done to evaluate the impact of philosophical inquiry method on low achievers' academic achievement.

\section{Acknowledgements}

The funding for this research project was granted by Research Management Centre, International Islamic University Malaysia. 


\section{References}

Appleton, J. J., Christenson, S. L., \& Furlong, M. J. (2008). Students engagement with school: Critical conceptual and methodological issues of the construct. Psychology in Schools, 45(5), 369-386. https://doi.org/10.1002/pits.20303

Audas, R., \& Willms, J. D. (2001). Engagement and dropping out of school: A life course perspective. Human Resources and Social Development Canada. Retrieved November 2002, from http://www.hrsdc.gc.ca/en/cs/sp/hrsd/pre/publications/ research/2001-000175/SP-483-01-02E.pdf

Barrow, W. (2011). A Dialogic Exploration of Philosophy for Children as a Participatory Tool in a Primary Classroom. Unpublished Thesis of Doctorate in Educational Psychology, School of Education, Communication and Language Science.

Battin-Pearson, S., Newcomb, M. D., Abbot, R. D., Hill, K. G., Catalano, R. F., \& Hawkins, J. (2000). Predictors of early high school dropout: A test of five theories. Journal of Educational Psychology, 92, 568-582. https://doi.org/10.1037/0022-0663.92.3.568

Bobacova, D., Geckova, A. M., Klein, D., Dijk, J. P. V., \& Reijneveld, S. A. (2015). Fighting, truancy, low academic achievement in youth subcultures. YOUNG, 23(4), 357-372. https://doi.org/10.1177/1103308815596905

Bryant, A. L., Schulenberg, J. E., O’Malley, P. M., Bachman, J. G., \& Johnson, L. D. (2003). How academic achievement, attitudes, and behaviors realated to course of substance use during adolescence: A 6-year, multiwave national longitudinal study. Journal of Research on Adolescence, 13(3), 361-397. https://doi.org/10.1111/1532-7795.1303005

Cam, P. (1995). Thinking together: Philosophical inquiry for the classroom. Sydney: Australia: Hale \& Iremonger Pty. Ltd.

Cam, P. (2006). Philosophy and the school curriculum: Some general remarks. Paper presented at the Conference of Philosophy in School: Developing Community of Inquiry. Organized by Singapore Teachers’ Union. April 17-18.

Capella, E., \& Weinstein, R. (2001). Turning around reading achievement: Predictors' of high school students’ academic resilience. Journal of Educational Psychology, 93, 758-771. https://doi.org/10.1037/0022-0663.93.4.758

Cassidy, C. (2013). Philosophy with Children: Learning to Live Well. Childhood and Philosophy, 8(16), $243-264$.

Chakrabarty, A. K., \& Saha, B. (2014). Low achievers at elementary stages of EFL learning: The problems and possible way-outs. International Journal on New Trends in Education and Their Implications, 5(3), $160-165$.

Christenson, S. L., Sinclair, M. F., Lehr, C. A., \& Godber, Y. (2001). Promoting successful school completion: Critical conceptual and methodological guidelines. School Psychology Quarterly, 16, 468-484. https://doi.org/10.1521/scpq.16.4.468.19898

Christenson, S. L., Reschly, A. L., \& Wylie, C. (Eds.). (2012). Handbook of research on student engagement. New York, NY: Springer Science. https://doi.org/10.1007/978-1-4614-2018-7

Colom, R., Mariyon, F.G., Magro, C., \& Morilla, E. (2014). The Long-term Impact of Philosophy for Children: A Longitudinal Study (Preliminary Results). Analytic teaching and philosophical praxis, 35(1), 50-56.

Connell, J. P., Spencer, M. B., \& Aber, J. L. (1994). Educational risk and resilience in African-American youth: Context, self, action, and outcomes in school. Child Development, 65, 493-506. https://doi.org/10.2307/1131398

Crumpton, H. E., \& Gregory, A. (2011). “I’m not learning”: The role of academic relevancy for low achieving students. The Journal of Educational Research, 104(1), 42-53. https://doi.org/10.1080/00220670903567398

Dasí, M.G., Quintanilla, L., \& Daniel, M.F. (2013). Improving Emotion Comprehension and Social Skills in Early Childhood Through Philosophy for Children. Childhood \& philosophy, 9(17), 63-89.

Dotterer, A., \& Lowe, K. (2011). Classroom context, school engagement and academic achievement in early adolescents. Journal of Youth \& Adolescence, 40(12), 1649-1660. https://doi.org/10.1007/s10964-011-9647-5

Elder, L., \& Paul, R. (2003). Critical thinking: teaching students how to study and learn (Part IV). Journal of Developmental Education, 27(2), 36-8. 
Ellis, J., Hart, S., \& Small-McGinley, J. (2001). Encouraging the discouraged: Students' views for elementary classrooms. Analytic Teaching, 22(1), 20-36.

Ergle, K. A. V. (2003). Barriers to low achievers' success in the elementary classroom as perceived by teachers: A qualitative study. Unpublished $\mathrm{PhD}$ dissertation to the Graduate School of the University of Florida.

Faira, F., Haasa, L.E., Gardosikb, C., Johnsona, D.D., Pricea, D.P., \& Leipnika, O. (2015). Socrates in the schools from Scotland to Texas: Replicating a study on the effects of a Philosophy for Children program. Journal of Philosophy in Schools, 2(1), 18-37. https://doi.org/10.21913/JPS.v2i1.1100

Felson, R. B., \& Staff, J. (2006). Explaining academic performance and delinquency relationship. Criminology, 44(2), 299-320. https://doi.org/10.1111/j.1745-9125.2006.00050.x

Finn, J. D., \& Rock, D. A. (1997). Academic success among students at risk for school failure. Journal of Applied Psychology, 82, 221-234. https://doi.org/10.1037/0021-9010.82.2.221

Fredericks, J. A., Blumenfeld, P. C., \& Paris, A. H. (2004). School engagement: Potential of the concept, state of the evidence. Review of Educational Research, 74, 59-109. https://doi.org/10.3102/00346543074001059

Furlong, M. J., \& Christenson, L. S. (2008). Engaging students at school and with learning: A relevant construct for all students. Psychology in the Schools, 45(5), 365-368. https://doi.org/10.1002/pits.20302

Gasparatou, R., \& Kampeza, M. (2012). Introducing P4C in Kindergarten in Greece. Analytic Teaching and Philosophical Praxis, 33(1), 72-82.

Ghaedi, Y., Mahdian, M., \& Fomani, F.K. (2015). Identifying Dimensions of Creative Thinking in Preschool Children during Implementation of Philosophy for Children (P4C) Program: A Directed Content Analysis. American Journal of Educational Research, 3(5), 547-551.

Gilles, R. M. (2015). Dialogic interactions in the cooperative classroom. International Journal of Educational Research, 76, 178-189. http://dx.doi.org/10.1016/j.ijer.2015.02.009

Golding, Clinton. (2006). What are philosophical questions? Paper presented at the Conference of Philosophy in Schools: Developing a Community of Inquiry. Organized by Singapore Teachers' Union. April 17-18.

Gorard, S., Siddiqui, N., \& See, B.H. (2016). Can 'Philosophy for Children' improve primary school attainment? Journal of Philosophy of Education, 51(1), 5-22. https://doi.org/10.1111/1467-9752.12227

Guay, Boivin, \& Marsh. (2003). Academic self-concept and academic achievement: Developmental perspectives on their causal ordering. Journal of Educational Psychology, 95(1), 124-136. https://doi.org/10.1037/0022-0663.95.1.124

Haynes, J., \& Murris, K. (2011). The provocation of an epistemological shift in teacher education through philosophy with children. Journal of Philosophy of Education, 45(2), 286-303. https://doi.org/10.1111/j.1467-9752.2011.00799.x

Ishak, Z., \& Fin, L. S. (2015). Factors contributing to truancy among students: A correlation between predictors. British Journal of Education, Society \& Behavioural Sciences, 9(1), 32-39. https://doi.org/10.9734/BJESBS/2015/17313

Jenkins, P., \& Lyle, S. (2010). Enacting dialogue: the impact of promoting Philosophy for Children on the literate thinking of identified poor readers, aged 10. Language and Education, 24(6), 459-472. https://doi.org/10.1080/09500782.2010.495781

Jimerson, S. R., Campos, E., \& Greif, J. L. (2003). Toward an understanding of definitions and measures of school engagement and related terms. California School Psychologist, 8, 7-27. https://doi.org/10.1007/BF03340893

Jones, J. R. (2013). The relationship between early high school discipline and academic outcomes. Unpublished PhD dissertation presented to the State University of New Jersey.

Jones, T. (2102). Community in the classroom: An approach to curriculum and instruction as a means for the development of student personal engagement in a high school classroom. Educational Perspectives, 44(1\&2), 58-64.

Juhasni Adila Juperi. (2010). Philosophical inquiry in Islamic education and its effect in the development of questioning skills among secondary school students. Unpublished project paper submitted as a course requirement for the Degree of Master of Education, International Islamic University Malaysia. 
Kamal, M., \& Bener, A. (2009). Factors contributing to school failure among school children in a very fast developing Arabian society. Oman Medical Journal, 24(3), 212-217.

Kennedy, E. (2010). Narrowing the achievement gap: Motivation, engagement and self-efficacy matter. Journal of Education, 190(3), 1-11. https://doi.org/10.1177/002205741019000302

Legault, L. Demers, I. G., \& Pelletier, L. (2006). Why do students lack motivation in classroom? Toward an understanding of academic amotization and the role of social support. Journal of Educational Psychology, 98(3), 567-582. https://doi.org/10.1037/0022-0663.98.3.567

Letseka, M.M. (2014). Africanising Philosophy for Children (P4C) in the South African Context. Mediterranean Journal of Social Sciences, 5(9), 348-355.

Lipman, M. (2003). Thinking in education ( $2^{\text {nd }}$ ed.). New York: Cambridge University Press. https://doi.org/10.1017/CBO9780511840272

Marks, H. M. (2000). Student engagement in instructional activity: Patterns in the elementary, middle, and high school years. American Educational Research Journal, 37, 153-184. https://doi.org/10.3102/00028312037001153

Maynard, B. R., Sales-Wright, C. P., Vaughn, M. G., \& Peters, K. E. (2012). Who are truant youth? Examining distinctive profile of truant youth using latent profile analysis. Journal of Youth Adolescence, 41, 1671-1684. https://doi.org/10.1007/s10964-012-9788-1

McCoach, D. B. (2001). A comparison of high achievers' and low achievers' attitudes, perceptions and motivations. Academic Exchange, 71-76.

Merriam, S.B. (1988). Case study research in education. San Francisco: Jossey-Bass.

Mijinyawa, S. I., Bakar, N. A., \& Muhammad, A. U. (2015). Approaches to solve the problem of truancy among secondary school students in Kuala Terengganu, Malaysia. IOSR Journal of Research \& Method in Education, 5(4), 63-70.

Millet, S., \& Tapper, A. (2013). Benefits of Collaborative Philosophical Inquiry in Schools. Educational Philosophy and Theory, 44(5), 546-567. https://doi.org/10.1111/j.1469-5812.2010.00727.x

Murphy, P. K., Wilkinson, I. A. G., Soter, A. O., Hennessey, M. N., \& Alexander, J. F. (2009). Examining the effects of classroom discussion on students' comprehension of text: A meta-analysis. Journal of Educational Psychology, 101(3), 740-764. https://doi.org/10.1037/a0015576

Nelson, L. (1993). The Socratic method. In M. Lipman (ed.), Thinking children and education (pp. 437-443). Dubuque, Iowa: Kendall/Hunt Publishing Company.

Preece, A. S. (2012). Benefitting Muslim learner's using philosophical inquiry. Paper presented at $21^{\text {st }}$ MELTA International Conference, Kuala Lumpur.

Reeve, J. (2013). How students create motivationally supportive learning environments for themselves: The concept of agentic engagement. Journal of Educational Psychology, 105, 579 -595. https://doi.org/10.1037/a0032690

Reeve, J., \& Tseng, M. (2011). Agency as a fourth aspect of student engagement during learning activities. Contemporary Educational Psychology, 36, 257-267. https://doi.org/10.1016/j.cedpsych.2011.05.002

Reiss, S. (2009). Six motivational reasons for low school achievement. Child Youth Care Forum, Springer Science and Business Media, 38(4), 219-225. https://doi.org/10.1007/s10566-009-9075-9

Reyes, M. R., Brackett, M. A., Rivers, S. E., White, M., \& Salovey, P. (2012). Classroom emotional climate, student engagement and academic achievement. Journal of Educational Psychology, 104(3), 700-712. https://doi.org/10.1037/a0027268

Rogers, T., \& Feller, A. (2016). Discouraged by peer excellence: Exposure to exemplary peer performance causes quitting. Psychological Science Online First, 27(3), 1-10. https://doi.org/10.1177/0956797615623770

Rosnani Hashim. (2012). Memenuhi aspirasi kemahiran berfikir dalam pelan pembangunan pendidikan Malaysia 2013-2025 menerusi inkuiri dan pedagogi filosofiyyah dalam kalangan guru (Fulfilling the aspiration of thinking skills in Malaysia Education Blueprint 2013-2025 through pedadogy of philosophical inquiry among teachers). Paper presented at the Dean's Council for Faculty of Education Conference, University Technology Malaysia, Johor Bahru. 7-9 October. 
Ross, G. M. (1993). Socrates versus Plato: The origins and development of Socratic thinking. Aspects of Education 49, 9-22; reprinted in Thinking: The Journal of Philosophy for Children, 12(4), 2-8.

Rubin, B. C. (2006). Aware, complacent, discouraged, empowered: Students' diverse civic identities. Social Studies Research and Practice, 1(2), 223-232.

Sagor, R., \& Cox, J. (2004). At risk students: reaching and teaching them. New York: Eye on Education.

Schjelderup, A. (2009). Learning science through philosophical dialogues. Farhang Journal of Iran Institute for Humanities and Cultural Studies, 22(69), 1-14.

Shaywitz, B., Holford, T., Holahan, J., Fletcher, J., Steubing, K., \& Francis, D. (1995). A Matthew effect for IQ but not for reading: Results from a longitudinal study. Reading Research Quarterly, 30, 894-906. https://doi.org/10.2307/748203

Sheryl, A. H., Stephanie, M. P., Herrenkohl, T. I., Toumbourou, J. W., \& Catalano, R. F. (2014). Student and school factors associated with school suspension: A multilevel analysis of students in Victoria, Australia and Washington State, United States. Child Youth Serv. Rev., 36(1), 187-194.

Sinclair, M. F., Christenson, S. L., Lehr, C. A., \& Anderson, A. R. (2003). Facilitating school engagement: Lessons learned from Check \& Connect longitudinal studies. California School Psychologist, 8, 29-41. https://doi.org/10.1007/BF03340894

Skinner, E., \& Belmont, M. J. (1993). Motivation in the classroom: Reciprocal effects of teacher behavior and student engagement across the school year. Journal of Educational Psychology, 85, 571-581. https://doi.org/10.1037/0022-0663.85.4.571

Skinner, E., Kindermann, T. A., Connell, J. P., \& Wellborn, J. G. (2009). Engagement and disaffection as organizational constructs in the dynamics of motivational development. In K. Wentzel \& A. Wigfield (Eds.), Handbook of motivation in school (pp. 223-245). Mahwah, NJ: Erlbaum.

Skinner, E., Furrer, C., Marchand, G., \& Kindermann, T. (2008). Engagement and disaffection in the classroom: Part of a larger motivational dynamic? Journal of Educational Psychology, 100(4), 765-781.

Slakmon, B., \& Schwartz, B. B. (2014). Disengaged students and dialogic learning: The role of CSCL affordances. International Journal of Computer-Supported Collaborative Learning, 9(2), 157-183. https://doi.org/10.1007/s11412-014-9191-x

Spiteri, D. (2009). Philosophy for Children: Appraising its impact on college level students. Childhood \& philosophy, 5(10), 425-445.

Spiteri, D. (2013). Can my perceptions of the 'other' change? Challenging prejudices against migrants amongst adolescent boys in a school for low achievers in Malta. Research in Education, 89, 41-60. https://doi.org/10.7227/RIE.89.1.4

Topping, K.J., \& Trickey, S. (2014). The role of dialog in philosophy for children. International Journal of Educational Research, 63, 69-78. https://doi.org/10.1016/j.ijer.2013.01.002

Tremblay, R. E., Masse, B., Perron, D., Leblanc, M., Schwartzman, A. E., \& Ledingham, J. E. (1992). Early disruptive behavior, poor school achievement, delinquent behavior, and delinquent personality: Longitudinal analysis. Journal of Consulting and Clinical Psychology, 60(1), 64-72. https://doi.org/10.1037/0022-006X.60.1.64

Walker, C. M., Wartenberg, T. E., \& Winner, E. (2012). Engagement in philosophical dialogue facilitates children's reasoning about subjectivity. Developmental Psychology, 49(7),1338-1347. https://doi.org/10.1037/a0029870

Wan Mazwati, W. Y., \& Lina Mursyidah, H. (2016). Philosophical inquiry method for enhancing higher order thinking in teaching aqidah to form two students. In Tengku Sarina Aini, T.K., Asyraf Isyraqi, J., Ahmad, Y., Mohd Anuar, M., Adama, B., \& Abd Aziz, R. (eds.), Pendidikan Islam dan cabaran globalisasi, pp. 303-331. Kuala Lumpur: Akademi Pengajian Islam, University Malaya.

Wang, M. T., \& Eccles, J. S. (2013). School context, achievement motivation, and academic engagement: A longitudinal study of school engagement using multidimensional perspectives. Learning and Instruction, 28, 12-23. https://doi.org/10.1016/j.learninstruc.2013.04.002

Wang, M. T., \& Eccles, J. S. (2012). Adolescent behavioural, emotional and cognitive engagement trajectories in school and their differential relations to educational success. Journal of Research on Adolescence, 22, 31-39. 
https://doi.org/10.1111/j.1532-7795.2011.00753.X

Wang, M. T., \& Holcombe, R. (2010). Adolescents’ perception on school environment, engagement and academic achievement in middle school. American Educational Research Journal, 47, 633-662. https://doi.org/10.3102/0002831209361209

Williamson, G., Applebaum, M., \& Epanchin, A. (1991). Longitudinal analysis of academic achievement. Journal of Educational Measurement, 28, 61-76. https://doi.org/10.1111/j.1745-3984.1991.tb00344.x

Willms, J. D. (2003). Student engagement at school: A sense of belonging and participation. Paris: Organisation for Economic Co-Operation and Development.

Yin, R. K. (1984). Case Study Research: Design and Methods. Beverly Hills: Sage Publications.

Yin, R. K. (1992). The case study method as a tool for doing evaluation. Current Sociology, 40(1), $121-137$. https://doi.org/10.1177/001139292040001009

Youssef, C. (2014). A Multilevel Investigation into the Effects of the Philosophical Community of Inquiry on 6th Grade Students' Reading Comprehension, Interest in Maths, Self-Esteem, Pro-Social Behaviours and Emotional Well-Being. Unpublished dissertation for Doctor of Philosophy School of Cultural and Professional Learning Faculty of Education, Queensland University of Technology.

Youssef, C., Campbell, M., \& Tangen, D. (2016). The Effects of Participation in a P4C Program on Australian Elementary School Students. Analytic Teaching and Philosophical Praxis, 37(1), 1-19.

Zhang, B., Zhao, J. W., \& Yu, G. (2010). Brief report: How do they manage social interaction? The influence of concealing academic achievement information on self-monitoring by adolescents with low achievement. Journal of Adolescence, 33, 233-236. https://doi.org/10.1016/j.adolescence.2009.07.003 